\title{
STUDENT PERCEPTIONS REGARDING THE NEW tRaining PROGRAMme for ChaRTERED ACCOUNTANTS
}

\author{
Gretha Steenkamp * \\ University of Stellenbosch \\ gvn@sun.ac.za
}

February 2012

\begin{abstract}
The South African Institute of Chartered Accountants (SAICA) recently introduced a competencybased accreditation process for chartered accountants (CAs). This changed the structure of the practical training period or 'articles' (which is now called the CA 2010 training programme). The new training programme has an increased focus on developing 'pervasive skills' (which include personal and professional skills, such as leadership, communication and ethics), and allows trainees to gain detailed experience in a specific focus area. Students, who would be affected by these changes, were surveyed regarding their perceptions of this new training programme. The students were positive about the focus on pervasive skills. However, many felt that the changes (especially the elective focus area) were communicated too late, as they had already signed with auditing firms, and would be forced into an auditing focus area. Many students were worried about possible changes to Part II of the Qualifying Examination ( $(2 \varepsilon 2)$.
\end{abstract}

\section{Keywords}

Student perceptions, CA 2010 training programme, Competency framework, Chartered accountant, Elective skills, Pervasive skills

\footnotetext{
*Ms Gretha Steenkamp a senior lecturer at the Department of Accountancy, University of Stellenbosch, South Africa.
} 


\section{INTRODUCTION}

Internationally, many professional accountancy bodies are moving away from a purely knowledge-based accreditation process for new members and are requiring new members to have attained certain identified competencies before they can register as professional accountants. Locally, the South African Institute of Chartered Accountants (SAICA) recently developed a competency framework detailing the skills a South African chartered accountant (hereafter referred to as CA(SA)) should possess when qualifying (SAICA, 2009a).

Flowing from this, a new training programme ('articles') for prospective CA(SA)s was also announced, and was called the CA 2010 training programme. The new training programme was developed, after a consultation process, to guide a prospective $C A(S A)$ to master the competencies required by the competency framework. It merges the previous Training inside Public Practice (TIPP) and Training outside Public Practice (TOPP) programmes, and aims to deliver a training programme that is adaptable to more training offices' needs and normal business activities. The CA 2010 training programme is effective for all trainee accountants who started their articles from 1 January 2010 onwards (SAICA 2009a).

SAICA conducted several information sessions regarding the CA 2010 training programme and accompanying competency framework at universities and training offices. One of these sessions was presented to post-graduate students who were completing a Certificate of Theory in Accounting (CTA) at a residential university. The new training programme applies to these students because they started their articles after writing Part I of the Qualifying Examination ( $P \varepsilon 1)$ in January 2010. Their training contracts would, therefore, be the first that have to comply with the new rules and structure of the CA 2010 training programme. During and after the information session presented by SAICA, several students expressed their concern and uncertainty regarding what effect the changed training programme will have on their future careers.

\section{RESEARCH OBJECTIVE AND CONTRIBUTION}

The purpose of this article was to investigate the perceptions of South African accountancy students regarding the new CA 2010 training programme and to determine the specific aspects they are concerned or uncertain about. This was done as an exploratory study, to facilitate a broad understanding of the views of the students.

These perceptions could help SAICA in assessing the satisfaction of all relevant stakeholders, in refining the training programme and by directing communication with stakeholders. The perceptions of students are important given the current shortage of trainees, as a negative perception regarding the training programme could deter students from entering and completing accountancy study. These findings could also be useful to training officers at firms offering a training programme, helping them to understand the misgivings and uncertainties of their trainees and enabling them to address these uncertainties during the training process.

This research is relevant to South African academics seeking to integrate the competency framework's requirements into their academic syllabus. It is necessary to understand the students' perceptions regarding the CA 2010 training programme and accompanying competency framework, which might affect the way any changes in the academic programme are received. In addition, this research could be useful to lecturers who have to train and advise students, by 
giving the lecturers insight into the possible concerns and questions students might have regarding the training programme.

The article adds to the debate regarding the way in which chartered accountants should be trained and which skills they should possess, as well as the usefulness of a competency-based approach for entry into the accounting profession. The findings are significant because they expand the literature by focusing on the perceptions of prospective trainee accountants in the South African context, which is a relatively unexplored topic.

\section{RESEARCH METHODOLOGY}

\subsection{Overall research design and method}

As the research objective was to test the perceptions of accountancy students regarding the new CA2010 training programme, an empirical study was decided upon to gather the necessary primary data. The empirical study was conducted using a survey that was specifically developed for this reason (see section 3.2 for further details regarding the survey instrument and its development). The survey was administered to CTA students who would be affected by the changes (see section 3.3 for further details), and their responses were analysed statistically to draw conclusions about their perceptions (see section 3.4 for further details). A literature review was also done to explain the research question adequately, guide the development of the survey instrument and interpret the responses gathered (see section 4 ).

\subsection{Survey instrument (including development)}

The survey consisted of three parts. The first part specifically asked for details regarding the type of training office at which the student had signed a training contract, as well as his/her gender. This was asked to determine whether the sample was representative of the population of CTA students and trainee accountants in South Africa, and to allow a comparison of the perceptions of students signed with the different types of training offices and of different genders. In the second part of the survey students were asked to indicate whether or not they agreed with several statements, using the following Likert scale: 1 (Agree), 2 (Agree somewhat), 3 (Neutral), 4 (Disagree somewhat), and 5 (Disagree or Disagree completely). The third part contained a single open-ended question, asking for any additional comments.

The survey was initially drawn up in Afrikaans and later translated to English. The survey was administered in both languages. In translating the survey, a slight inconsistency occurred. The Afrikaans survey used the term 'Verskil heeltemal' (meaning 'Disagree completely') when defining number 5 on the Likert scale mentioned above. However, the English survey merely used the term 'Disagree'. 'Disagree' would be the more correct version, considering that number 1 on the Likert scale is 'Agree' (or 'Stem saam'). This slight tonal difference was, however, considered insignificant in terms of reviewing the findings of the article, for two reasons:

- Because a Likert scale was used, it would be obvious to the students that they had to rank their perceptions between agree and disagree. Also, there is little difference in meaning between 'disagree' and 'disagree completely' - it is mostly a difference in tone.

- The responses of the students primarily ranged between 'agree' and 'neutral' (only $6.44 \%$ of the responses were 'disagree somewhat' or 'disagree'). 
The statements contained in the second part of the survey were developed to test students' perceptions relating to the value of the CA(SA) qualification (in South Africa and internationally), the need for a training programme, the new training programme itself, the reasons for the development of the new training programme, the desirability of the changes brought about by the new training programme, the effect that the implementation of the new training programme will have on students and their choice of training offices as well as the uncertain format of Part II of the Qualifying Examination ( $P \varepsilon 2$ ). These aspects were deemed to cover all possible concerns of the students and effects of the implementation.

Some of the statements were developed based on SAICA information regarding the CA 2010 training programme (SAICA, 2009a; SAICA, 2009b) to enable an understanding of whether students agreed with this information or not. The rest of the statements were developed by deducing possible concerns about and effects of the implementation of the training programme. These deductions were made by comparing the old and new training programmes (to highlight differences) and from discussions with students and lecturers after the SAICA information session.

\subsection{Data collection}

In 2009, the survey was distributed to the 205 students enrolled during 2009 for the CTA programme at a residential university. The survey was handed out in class (in Afrikaans), and 72 (35\%) of the students completed it in a paper format. In 2010, the response rate was reviewed and found to be lacking. The students (in the CTA class of 2009) who had not completed the survey initially were identified using a complete class list. The survey was re-sent or given to those students who had not previously completed the survey and whose email addresses or whereabouts were known. The survey was also translated into English at this point, which might have increased the possible responses. An additional 40 responses, in electronic and paper format, were gathered in this manner. In total 112 students completed the survey in paper or electronic format, leading to a total response rate of $55 \%$.

\subsection{Data analysis}

The data from the completed surveys was transferred to an electronic spreadsheet, which tabled the responses from each student. The general information contained in the first part of the survey was evaluated to determine at which training offices the students had signed a contract to complete their articles, as well as their gender. This was done to ascertain if the biographical profile of respondents was similar to that of South African CTA students and trainee accountants in general.

The data from the second part of the survey was evaluated per statement. The responses $(1,2,3$, 4 or 5 ) to each statement were summarised and a mean score (between $l$ and 5) as well as standard deviation was calculated for each statement using spreadsheet functions. The data set was then inputted into STATISTICA (statistics software) and analysed further. As the data collected was in the form of a Likert scale and, therefore, ordinal (but not necessarily normally distributed), Mann-Whitney U-tests were done to identify instances where the responses to a specific statement differed significantly between students who held training contracts from different types of training offices, and between genders. The Mann-Whitney U-test is a nonparametric test to determine whether two sets of independent observations differ significantly 
in value. All differences that were significant at a $p=.05$ or $5 \%$ level of significance were discussed.

The qualitative responses received in response to the third part of the survey (the single openended question asking for additional comments) were reviewed separately from the other quantitative data. A total of 24 students included narrative, qualitative comments in their response. The comments made by these students were tabled to count the number of times that a specific comment was made. All comments that were made only once were not discussed in the article, as this was deemed to be a single student's opinion and not representative of the group. Whenever a specific comment was made more than once, this was seen as more significant. Such qualitative responses are discussed under the appropriate aspect to which they relate (see 5.2).

\section{LITERATURE REVIEW}

The competencies (including technical knowledge, skills and attitudes) required from chartered accountants have changed dramatically in the last 20 years due to changes in the business world, such as an increase in the availability of and usage of information technology (IT), changing needs of clients, increased complexity, globalisation, negative publicity due to accounting scandals such as Enron, WorldCom and others, as well as increased regulation of companies both locally and internationally (Barac, 2009; SAICA, 2009a; SAICA, 2009b; Wessels \& Steenkamp, 2009; Dellaportas, 2006; Bolt-Lee \& Foster, 2002; Albrecht \& Sack, 2000; Saemann \& Crooker, 1999).

Although technical accountancy knowledge has remained important, the changes above have increased the relevance of 'non-technical' skills such as an ethical approach, professionalism, analytical/critical thinking, problem-solving skills, innovation, change management, general business acumen, knowledge of corporate governance, international strategy, an understanding of the role of IT, effective use of IT, communication (written/oral), interpersonal skills as well as leadership qualities and teamwork (Barac, 2009; Ibrahim \& Angelidis, 2009; SAICA, 2009a; SAICA, 2009b; Wessels \& Steenkamp, 2009; Jeacle, 2008; Palmer, Ziegenfuss \& Pinsker, 2004; Bolt-Lee \& Foster, 2002; Albrecht \& Sack, 2000; Saemann \& Crooker, 1999). Many of these skills were not addressed sufficiently by the previous SAICA training programme (SAICA, 2009b).

\subsection{Competency-based training internationally}

Competency-based accreditation is often implemented because of dissatisfaction with the preparation of candidates by the current system (Boritz \& Carnaghan, 2003), and consequently many professional accountancy bodies internationally have developed models that stipulate the competencies (as opposed to the knowledge) an accountant should possess for membership. According to the International Federation of Accountants (2008), competence is 'being able to perform a work role to a defined standard, with reference to real working environments'. These competency frameworks focus on the application of technical knowledge, coupled with nontechnical skills.

Using a competency-based process for accreditation could lead to a higher level of correlation between business requirements and actual capabilities of candidates, as input from practitioners is used in developing the competencies (Palmer, Ziegenfuss \& Pinsker, 2004). It could also lead to greater transparency regarding the nature of the professional's work if competencies are communicated (Boritz \& Carnaghan, 2003), as well as improved accountability 
in the light of recent accounting scandals (Palmer, Ziegenfuss \& Pinsker, 2004; Boritz \& Carnaghan, 2003). However, implementation could be expensive and assessment of the competencies can be complex (Boritz \& Carnaghan, 2003).

Currently the Institute of Chartered Accountants in Australia (ICAA), the Canadian Institute of Chartered Accountants (CICA), the American Institute of Certified Public Accountants (AICPA), the Institute of Chartered Accountants in Ireland (ICAI), as well as SAICA have competencydriven requirements for membership. Although the frameworks of the different institutes differ in style, their content is very similar, focusing on the use of IT, ethics, personal skills/attributes (such as leadership, self-management and professional development), professional skills (such as communication, problem-solving and critical thinking) as well as technical competency areas (accounting and external reporting, management accounting, auditing and assurance, financial management, taxation as well as governance, strategy and risk management) (CICA, 2011; ICAI, 2011; ICAA, 2010; SAICA, 2008; AICPA, 2005).

\subsection{The South African CA 2010 training programme}

The new competency framework developed by SAICA stipulates the competencies that a chartered accountant should possess upon qualifying (SAICA, 2009a). It provides for an academic component (culminating in the successful completion of $D E 1$ ) as well as a practical training programme (commonly referred to as 'articles'). The new CA 2010 training programme (which is competency-based) replaces the old training programme, which had both TIPP and TOPP programmes (SAICA, 2009a).

The skills that should be developed during the new CA 2010 training programme are divided into three categories: compulsory skills, elective skills and residual skills (SAICA, 2009a). Compulsory skills include pervasive professional skills (such as ethics, communication skills and leadership) as well as accounting and external reporting (SAICA, 2009b). Under elective skills a trainee can develop skills in one or more of the available focus areas, which are (1) strategy, risk management \& governance, (2) financial management, (3) auditing \& assurance, (4) taxation and (5) management decision-making (SAICA, 2009a). The focus area is determined by the industry and business activities of the training office (SAICA, 2009b). The trainees should gain detailed experience in both the compulsory and elective skills during the training programme (SAICA, 2009a). Residual skills refer to a basic exposure to the remaining focus areas (those not chosen as an elective) (SAICA, 2009b).

\subsection{Comparing the new CA 2010 training programme and the previous South African training programme}

Under the previous training programme, a trainee was either training in TIPP (focusing on auditing) or in TOPP (focusing on management accounting), with specific competencies prescribed for each programme. The emphasis was also placed most heavily on auditing, as most trainees were in TIPP. Under the new CA 2010 training model this distinction between TIPP and TOPP falls away, and trainees should be thoroughly competent in all compulsory skill areas and at least one elective skill area (SAICA, 2009a). Furthermore, a basic level of competency should be achieved in all the remaining (residual) skill areas (SAICA, 2009a).

As such, one of the major changes is the decreased focus on auditing, and that it would be possible for a trainee to qualify as chartered accountant after gaining in-depth training in a 
field other than auditing or management accounting. A further, important change is the increased focus on the so-called pervasive professional skills, which should lead to a chartered accountant being a more balanced and business-orientated professional. The pervasive professional skills include the use of information technology, communication skills, knowledge of corporate governance, an ethical outlook as well as leadership skills (SAICA, 2009a).

Under the previous training programme (after completing 18 months of the training period), trainees were required to write $Q \varepsilon 2$, which was focused on testing either technical auditing or management accounting skills (depending on whether the trainee was in TIPP or TOPP). Because of the change in the training programme, the format and timing of the $Q \varepsilon 2$ also has to change. At the time of conducting the research (and administering the survey) the proposals in this regard had not yet been finalised. Currently, the amended format of $0 \varepsilon 2$ is under discussion, and potentially includes a case study method of testing, focusing less on technical skills and more on pervasive professional skills (SAICA, 2012).

\subsection{Comparing the South African CA 2010 training programme with other international models}

SAICA's new competency framework and CA 2010 training programme were based on the Canadian competency framework of CICA (Barac, 2009). The competencies contained in the South African model are almost identical to the Canadian one, although some differences exist in the application thereof. During the training programme, CICA allows a trainee the choice of gaining in-depth experience in any one of six technical competency areas (CICA, 2010), whereas SAICA prescribes accounting and external reporting and a choice of at least one other elective technical competency area (SAICA, 2008). Many competency frameworks allow for some mandatory and some elective competencies (Boritz \& Carnaghan, 2003), especially regarding the technical competencies. For example, in the ICAA's framework $100 \%$ competence must be obtained across one or more of the technical competency areas, which means that a person might have $100 \%$ competence in taxation, or $30 \%$ in taxation and $70 \%$ in accounting and external reporting (ICAA, 2010).

Some differences also exist regarding assessment through the final qualifying examination. SAICA had (at the stage the research was conducted) not yet communicated any final information regarding its proposed amendments to $Q \mathcal{E} 2$. CICA tests all technical competency areas in the final qualifying examination (CICA, 2011), whereas some other bodies allow for choices. For example, the ICAl's final qualifying examination has a mandatory section as well as a section where the candidate can choose to answer questions on audit and assurance, taxation or advanced performance management (ICAI, 2011).

\subsection{The importance of student perceptions}

A recent research project found that training officers believed that the new training programme would benefit trainees, but were still uncertain of what exactly the new training programme entailed (SAICA, 2009d). Barac (2009) mentioned that the perceptions of other stakeholders, of which post-graduate students as prospective trainee accountants are an example, should be examined regarding the CA 2010 training programme.

Previous international and local studies in which student perceptions of the accounting profession and its effect on their decision to study accountancy were tested, include Saemann 
and Crooker (1999), Geiger and Ogilby (2000) as well as Wessels and Steenkamp (2009). These studies showed that the perceptions of students played a pivotal role in their choice of career. In the light of this, the perceptions of students regarding the quality of the CA 2010 training programme is significant as it could affect a student's decision to studying accountancy.

\section{EMPIRICAL RESEARCH FINDINGS}

\subsection{Biographical details of respondents}

\subsubsection{Training offices}

All 112 students, who completed the survey, had signed training contracts at the time of the survey. A total of $109(97 \%)$ of these students had decided to complete their articles at previous TIPP firms, while only three (3\%) had signed contracts with TOPP firms. A total of 73 (65\%) had opted to be articled to the so-called 'Big Four' TIPP firms and 36 (32\%) held contracts from other TIPP firms. The 'Big Four' TIPP firms are the biggest four accounting firms internationally and are PricewaterhouseCoopers (PwC), Deloitte Touche Tohmatsu, Ernst \& Young and KPMG.

The above split between TIPP and TOPP firms, as well as the 'Big Four' and other TIPP firms, is very similar to the statistics published by SAICA (SAICA, 2009c) about the candidates who wrote a recent $Q \varepsilon l$ examination (2009). A comparison of the two groups (respondents to the survey and candidates who wrote 2009 ( $E$ l) can be seen in TABLE 1 . All $Q \varepsilon$ l ratios were based on a total that excludes the 'other' candidates, about whom no information regarding their training office was available on the SAICA website (SAICA 2009c).

TABLE 1: Comparison of respondents to candidates who wrote 2009 p 1

\begin{tabular}{ccc}
\hline Percentage of group articled to: & Candidates \\
who wrote \\
$2009 \rho \varepsilon 1$
\end{tabular}

Source: Created by author using data from SAICA, 2009C

\subsubsection{Gender}

Of the 112 students who completed the survey, $58(52 \%)$ were female and $54(48 \%)$ were male. This approximates the gender split in the recent $\rho \varepsilon l$ examination of 2009 , where $51 \%$ of the students who wrote the examination were female and $49 \%$ were male (SAICA 2009c).

\subsection{Summary of the findings on student perceptions}

The perceptions of the students were tested in regards to seven different aspects relating to the CA 2010 training programme. Each aspect is addressed separately below and was tested in two 
ways. Firstly, using a Likert scale, the students had to indicate whether they agreed with certain statements (the results of this can be seen in TABLES $\mathbf{2 - 8}$, which contain the mean responses as well as the standard deviations). Secondly, the students were asked for any other comments. These comments are also discussed under the aspect to which they relate.

\subsubsection{Value of the CA(SA) qualification}

The statements in TABLE 2 tested the perceptions regarding the prominence of the CA(SA) qualification in South Africa and internationally, to enable an understanding of whether the students still deemed the qualification worthwhile after the announcements of the new training programme.

The overwhelming majority felt that this was still the case, as the students' mean perception was 1.10 (close the 'Agree') regarding the statement that the CA(SA) qualification was the best accounting qualification in the RSA. The students were less certain that the CA(SA) qualification was the best business qualification in the RSA, but the mean rating was still 1.63 (between 'Agree' and 'Agree somewhat'). This does, however, emphasise the fact that the CA(SA) qualification is viewed as slightly less business-focussed. Two of the 24 students commented, in response to the open-ended question, that this change in training programme will make the qualification more business-orientated. The students believed that the CA(SA) qualification was recognised internationally and enjoyed status overseas (mean score 1.36 - closer to 'Agree'). Corresponding to this, the students would consider working overseas temporarily as a CA(SA) (mean score 1.42 - closer to 'Agree').

\section{TABLE 2: Perceptions regarding the value of the CA(SA) qualification}

\begin{tabular}{llcc}
\hline & $\begin{array}{c}\text { Mean score } \\
\text { (between 1 and 5) }\end{array}$ & $\begin{array}{c}\text { Standard } \\
\text { deviation of } \\
\text { score }\end{array}$ \\
\hline $2.1 \quad \begin{array}{l}\text { The } \mathrm{CA}(\mathrm{SA}) \text { qualification is the best / most prominent } \\
\text { professional accounting qualification in the RSA. }\end{array}$ & 1.10 & 0.33 \\
$2.2 \quad \begin{array}{l}\text { The } \mathrm{CA}(\mathrm{SA}) \text { qualification is the best / most prominent } \\
\text { business qualification in the RSA. }\end{array}$ & 1.63 & 0.82 \\
$2.3 \quad \begin{array}{l}\text { The CA(SA) is recognised internationally and is esteemed } \\
\text { highly internationally. }\end{array}$ & 1.36 & 0.68 \\
$2.4 \quad \begin{array}{l}\text { I will consider working overseas (temporarily) after I have } \\
\text { qualified as a CA(SA). }\end{array}$ & 1.42 & 0.83 \\
\hline
\end{tabular}

Source: Created by author

\subsubsection{The value of a training programme}

The statements in TABLE 3 tested the students' perceptions regarding the value of a training programme, to determine whether they deem it as necessary and why. Nearly all of the students agreed that a training programme is necessary (mean score of both statements were close to 1 'Agree'), and saw it as an important skills development process. This agrees with the findings of an earlier study done by SAICA $(2009 \mathrm{e})$ which indicated that trainees perceived the development of skills to be the most beneficial aspect of the previous SAICA training programme. 
TABLE 3: Perceptions regarding the value of a training programme

\begin{tabular}{|c|c|c|c|}
\hline & & $\begin{array}{l}\text { Mean score } \\
\text { (between } 1 \text { and 5) }\end{array}$ & $\begin{array}{l}\text { Standard } \\
\text { deviation } \\
\text { of score }\end{array}$ \\
\hline 3.1 & $\begin{array}{l}\text { It is important that a training programme exists during } \\
\text { which the theoretical concepts mastered at university can } \\
\text { be applied practically in the business world. }\end{array}$ & 1.08 & 0.33 \\
\hline 3.2 & $\begin{array}{l}\text { Articles create a platform of technical and professional } \\
\text { skills on which } C A(S A) \text { s can build their careers. }\end{array}$ & 1.19 & 0.49 \\
\hline
\end{tabular}

\section{Source: Created by author}

\subsubsection{The CA 2010 training programme}

The statements in TABLE $\mathbf{4}$ were deliberately asked in a wide, non-specific manner to determine the students' general perceptions of the CA 2010 training programme. Most of the students were positive, slightly positive or neutral about the new training programme, with the mean scores being around 2 'Agree somewhat' on both the statements.

TABLE 4: General perceptions of the CA 2010 training programme

\begin{tabular}{|c|c|c|c|}
\hline & & $\begin{array}{c}\text { Mean score } \\
\text { (between } 1 \text { and 5) }\end{array}$ & $\begin{array}{c}\text { Standard } \\
\text { deviation } \\
\text { of score }\end{array}$ \\
\hline 4.1 & $\begin{array}{l}\text { The new CA } 2010 \text { training programme is a good } \\
\text { programme. }\end{array}$ & 2.14 & 0.97 \\
\hline 4.2 & $\begin{array}{l}\text { Standards are maintained under the new CA } 2010 \text { training } \\
\text { programme. }\end{array}$ & 1.86 & 0.95 \\
\hline
\end{tabular}

\section{Source: Created by author}

On reviewing the narrative qualitative responses to the third part of the survey, six of the 24 students commented on the fact that they were uncertain how the new training programme will be implemented practically and what the effect it would have on them, their future work experience and employer. Three of the 24 students who made narrative comments, also said that the implementation process was inadequate, the communication vague and that there had been a lack of sufficient consultation.

\subsubsection{The reasons for the change in training programme}

The statements in TABLE $\mathbf{5}$ allowed the students opportunity to state whether or not they perceived the reasons for the change to be as communicated by SAICA, and which of the reasons they saw as most pertinent. The students mostly agreed with the reasons for the change (mean scores being between 1 'Agree' and 2 'Agree somewhat'). 
TABLE 5: Perceptions regarding the reasons for the change

\begin{tabular}{|c|c|c|c|}
\hline & & $\begin{array}{l}\text { Mean score } \\
\text { (between } 1 \text { and 5) }\end{array}$ & $\begin{array}{l}\text { Standard } \\
\text { deviation of } \\
\text { score }\end{array}$ \\
\hline 5.1 & $\begin{array}{l}\text { The fact that South Africa increasingly takes part in the } \\
\text { international economy necessitates a change in the } \\
\text { training. }\end{array}$ & 1.64 & 0.73 \\
\hline 5.2 & $\begin{array}{l}\text { The fact that businesses have become more complex } \\
\text { necessitates a change in the training. }\end{array}$ & 1.60 & 0.78 \\
\hline 5.3 & $\begin{array}{l}\text { The increasing use of information technology in the } \\
\text { business world necessitates a change in the training. }\end{array}$ & 1.54 & 0.76 \\
\hline 5.4 & $\begin{array}{l}\text { The increasing focus on ethics and ethical behaviour of } \\
\text { professional people necessitates a change in the training. }\end{array}$ & 1.86 & 1.04 \\
\hline 5.5 & $\begin{array}{l}\text { The increasing focus by businesses on corporate } \\
\text { governance necessitates a change in the training. }\end{array}$ & 1.77 & 0.87 \\
\hline 5.6 & $\begin{array}{l}\text { The future changes to the Companies Act necessitate a } \\
\text { change in the training. }\end{array}$ & 1.74 & 0.84 \\
\hline 5.7 & $\begin{array}{l}\text { The CA(SA) training has changed to make provision for the } \\
\text { different needs of the training offices and to be more } \\
\text { flexible. }\end{array}$ & 2.11 & 0.98 \\
\hline 5.8 & $\begin{array}{l}\text { In the past } 20 \text { years there have been many changes in the } \\
\text { world, which have also caused the skills required of a } \\
C A(S A) \text { to change. }\end{array}$ & 1.34 & 0.64 \\
\hline
\end{tabular}

\section{Source: Created by author}

The only statement for which the mean score was above 2 was about the change being made to provide more flexibility to training offices. This might be due to the students' limited experience of the functioning of a training office and its needs. The two statements agreed with the most concerned the increased use of information technology and the general changes that have taken place in the world in the past two decades, causing the skills required of a CA(SA) to change.

\subsubsection{The value of the main changes}

The perceptions of the students regarding the value of the main changes can be seen in TABLE 6 . The students perceived the increased focus on the development of leadership qualities, communication skills, the effective use of information technology as well as ethics and ethical behaviour, as positive (mean scores ranging between 1.3 and 1.6, between 'Agree' and 'Agree somewhat'). Three students mentioned (in their narrative comments to the third part of the survey) the fact that the teaching of ethics was problematic. Some mentioned that it could not really be taught or developed because it is an internal value. 
TABLE 6: Perceptions regarding the value of the main changes

\begin{tabular}{|c|c|c|c|}
\hline & & $\begin{array}{l}\text { Mean score } \\
\text { (between } 1 \text { and 5) }\end{array}$ & $\begin{array}{l}\text { Standard } \\
\text { deviation of } \\
\text { score }\end{array}$ \\
\hline 6.1 & $\begin{array}{l}\text { The fact that the programme increasingly focuses on } \\
\text { leadership development is positive. }\end{array}$ & 1.47 & 0.76 \\
\hline 6.2 & $\begin{array}{l}\text { The fact that the programme increasingly focuses on } \\
\text { communication skills is positive. }\end{array}$ & 1.39 & 0.69 \\
\hline 6.3 & $\begin{array}{l}\text { The fact that the programme increasingly focuses on the } \\
\text { effective use of information technology in the business } \\
\text { world is positive. }\end{array}$ & 1.33 & 0.58 \\
\hline 6.4 & $\begin{array}{l}\text { The fact that the programme increasingly focuses on } \\
\text { ethics and ethical behaviour is positive. }\end{array}$ & 1.57 & 0.86 \\
\hline 6.5 & $\begin{array}{l}\text { The fact that there is an elective focus area (e.g. auditing, } \\
\text { taxation) in the CA } 2010 \text { training programme is positive. }\end{array}$ & 2.15 & 1.23 \\
\hline
\end{tabular}

\section{Source: Created by author}

The students were less positive about the introduction of an elective focus area (last statement in TABLE 6). The mean score was 2.15 (close to 'Agree somewhat'). Five of the 24 students (who gave narrative responses) commented on the fact that the changes introduced by the new training programme should have been communicated earlier, allowing them to take it into account in their choice of training office and focus area. However, the students were generally positive about the opportunity to have a specific focus area (elective) and gain more balanced training which develops all aspects of a trainee's professional skills (six of the 24 students made comments in this regard).

\subsubsection{The effect that the changes will have on students and their choice of training offices}

The perceptions of the students regarding the effect that the changes will have on students and their choice of training offices can be seen in TABLE 7. The perceptions of the students wavered between agreeing somewhat and being neutral regarding whether the opportunity to develop skills outside of auditing would encourage more students to study accountancy.

The students agreed somewhat (mean scores between 1.6 and 1.9) that the existence of the focus areas or electives would cause

- students to be more circumspect about their choice of training office, as they would seek employment from a training office offering their preferred focus area,

- students to sign a training contract later in their studies, when they were more certain of their preference regarding focus areas, and

- training offices to change their marketing strategies, to include information about the focus areas offered by the specific firm. 
The elective focus area will draw more people to qualify as

7.1 a $C A(S A)$ because you don't only have to audit during your articles.

The fact that there is an elective focus area (e.g. auditing, taxation) in the 2010 training programme, will cause students to be more circumspect in their choice of a training firm.

The fact that there is an elective focus area (e.g. auditing,

7.3 taxation) in the 2010 training programme, will cause students to choose their training firm later in their studies.

The fact that there is an elective focus area (e.g. auditing,

7.4 taxation) in the 2010 training programme, will cause training firms to advertise themselves according to the elective focus areas they offer.

\section{Source: Created by author}

Four of the 24 students (who gave narrative responses) made comments relating to auditing firms and the offering of electives (focus areas). The students mentioned that the focus area would be determined by the training office where they were employed. As most of the firms offering training contract were auditing firms, the most common focus area would still be auditing \& assurance. Also, most students would still choose auditing \& assurance as this would be seen as the 'safest' option. In addition, four of the 24 students (who made narrative comments) felt that bigger auditing firms would be benefited by the changes brought about by the new training programme, as they could offer more of the focus areas.

\subsubsection{Part II of the Qualifying Examination ( $(p \varepsilon 2)$}

The perceptions of the students regarding $Q \varepsilon 2$ can be seen in TABLE 8. During the SAICA information session it was mentioned that SAICA intends to set only one $Q \varepsilon$ 2, i.e. trainees who have different focus areas would write the same final examination. The majority of the students felt uncertain about the format of the examination (mean score 1.48, between 'Agree' and 'Agree somewhat'), while some were even worried about it (mean score 2.43, between 'Agree somewhat' and 'Neutral'). Seven of the 24 students, who gave narrative comments, had concerns about the $\rho \varepsilon 2$ exam. The most common question was: how will the $\rho \varepsilon 2$ reliably test students who had been trained in different focus areas? Other concerns included the vagueness of communication in this regard, the future pass rate and the timing of the examination. 
TABLE 8: Perceptions about $\rho \varepsilon 2$

\begin{tabular}{clcc}
\hline & & $\begin{array}{c}\text { Mean score } \\
\text { (between I and 5) }\end{array}$ & $\begin{array}{c}\text { Standard } \\
\text { deviation of } \\
\text { score }\end{array}$ \\
\hline 8.1 I am uncertain about the format of the Part II exam. & 1.48 & 0.92 \\
8.2 I am worried about the format of the Part II exam. & 2.43 & 1.39 \\
\hline
\end{tabular}

\section{Source: Created by author}

\subsection{Comparing the responses of students of different training offices and genders}

The responses of the male and female students, as well as those from different training offices, were compared for each of the statements contained in TABLES $\mathbf{2}-\mathbf{8}$ (no comparison was made to the perceptions of those students who had signed with TOPP firms, as the sample of three respondents was deemed to be too small to draw any reliable conclusions). This was done by doing Mann-Whitney U-tests. All differences in perceptions that were significant at the $p=0.05$ level were discussed. The findings of this analysis can be seen in TABLE 9 . The findings contained in TABLE 9 were also scrutinised to determine if a specific trend was noticeable regarding the mean scores of the 'Big Four' versus 'Other' and Male versus Female subsections of the samplethis was done per aspect (i.e. for the statements contained in each of TABLES 2 - 8).

\section{TABLE 9: Comparing responses from students (different training offices and genders)}

\begin{tabular}{|c|c|c|c|c|c|c|}
\hline & \multicolumn{3}{|c|}{$\begin{array}{c}\text { Training contract with 'Big Four' versus in } \\
\text { other TIPP firms }\end{array}$} & \multicolumn{3}{|c|}{ Male versus Female } \\
\hline & $\begin{array}{c}\text { Mean } \\
\text { for } \\
\text { 'Big Four' }\end{array}$ & $\begin{array}{c}\text { Mean } \\
\text { for } \\
\text { 'Other' }\end{array}$ & $\begin{array}{c}\text { Mann } \\
\text { WhitneyU } \\
\text { p-value }\end{array}$ & $\begin{array}{c}\text { Mean } \\
\text { for } \\
\text { Male }\end{array}$ & $\begin{array}{c}\text { Mean } \\
\text { for } \\
\text { Female }\end{array}$ & $\begin{array}{c}\text { Mann } \\
\text { Whitney U } \\
\text { p-value }\end{array}$ \\
\hline \multicolumn{7}{|c|}{ Statements contained in TABLE 2: Perceptions regarding the value of the CA(SA) qualification } \\
\hline 2.1 & 1.11 & 1.08 & 0.91 & 1.07 & 1.12 & 0.78 \\
\hline 2.2 & 1.60 & 1.69 & 0.37 & 1.57 & 1.67 & 0.25 \\
\hline 2.3 & 1.37 & 1.31 & 0.76 & 1.40 & 1.33 & 0.50 \\
\hline 2.4 & 1.41 & 1.44 & 0.72 & 1.30 & 1.53 & 0.35 \\
\hline \multicolumn{7}{|c|}{ Statements contained in TABLE 3: Perceptions regarding the value of a training programme } \\
\hline 3.1 & 1.11 & 1.03 & 0.64 & 1.11 & 1.05 & 0.60 \\
\hline 3.2 & 1.19 & 1.17 & 0.92 & 1.19 & 1.19 & 0.73 \\
\hline \multicolumn{7}{|c|}{ Statements contained in TABLE 4: General perceptions of the CA 2010 training programme } \\
\hline 4.1 & 2.16 & 2.14 & 0.95 & 2.13 & 2.14 & 0.82 \\
\hline 4.2 & 1.79 & 2.08 & 0.27 & 2.02 & 1.72 & 0.14 \\
\hline \multicolumn{7}{|c|}{ Statements contained in TABLE 5: Perceptions regarding the reasons for the change } \\
\hline 5.1 & 1.66 & 1.64 & 0.95 & 1.63 & 1.66 & 0.59 \\
\hline
\end{tabular}




\begin{tabular}{|c|c|c|c|c|c|c|}
\hline & \multicolumn{3}{|c|}{$\begin{array}{c}\text { Training contract with 'Big Four' versus in } \\
\text { other TIPP firms }\end{array}$} & \multicolumn{3}{|c|}{ Male versus Female } \\
\hline & $\begin{array}{c}\text { Mean } \\
\text { for } \\
\text { 'Big Four' }\end{array}$ & $\begin{array}{l}\text { Mean } \\
\text { for } \\
\text { 'Other' }\end{array}$ & $\begin{array}{c}\text { Mann } \\
\text { WhitneyU } \\
\text { p-value }\end{array}$ & $\begin{array}{c}\text { Mean } \\
\text { for } \\
\text { Male }\end{array}$ & $\begin{array}{c}\text { Mean } \\
\text { for } \\
\text { Female }\end{array}$ & $\begin{array}{c}\text { Mann } \\
\text { Whitney U } \\
\text { p-value }\end{array}$ \\
\hline 5.2 & 1.66 & 1.50 & 0.35 & 1.69 & 1.52 & 0.45 \\
\hline 5.3 & 1.62 & 1.44 & 0.50 & 1.72 & 1.38 & 0.02 \\
\hline 5.4 & 1.90 & 1.81 & 0.47 & 2.07 & 1.66 & 0.07 \\
\hline 5.5 & 1.76 & 1.75 & 0.94 & 1.94 & 1.61 & 0.13 \\
\hline 5.6 & 1.74 & 1.72 & 0.98 & 1.85 & 1.64 & 0.31 \\
\hline 5.7 & 2.16 & 2.03 & 0.56 & 2.09 & 2.12 & 0.96 \\
\hline 5.8 & 1.31 & 1.44 & 0.42 & 1.38 & 1.31 & 0.51 \\
\hline \multicolumn{7}{|c|}{ Statements contained in TABLE 6: Perceptions regarding the value of the main changes } \\
\hline 6.1 & 1.36 & 1.71 & 0.03 & 1.47 & 1.47 & 0.95 \\
\hline 6.2 & 1.34 & 1.50 & 0.36 & 1.46 & 1.33 & 0.54 \\
\hline 6.3 & 1.29 & 1.39 & 0.42 & 1.43 & 1.24 & 0.12 \\
\hline 6.4 & 1.49 & 1.72 & 0.37 & 1.70 & 1.45 & 0.21 \\
\hline 6.5 & 2.10 & 2.31 & 0.55 & 2.26 & 2.05 & 0.53 \\
\hline \multicolumn{7}{|c|}{ Statements contained in TABLE 7: Perceptions of the effect of the changes } \\
\hline 7.1 & 2.17 & 2.39 & 0.41 & 2.43 & 2.05 & 0.18 \\
\hline 7.2 & 1.68 & 1.47 & 0.19 & 1.76 & 1.47 & 0.08 \\
\hline 7.3 & 1.90 & 1.75 & 0.32 & 1.94 & 1.76 & 0.19 \\
\hline 7.4 & 1.78 & 1.69 & 0.82 & 1.87 & 1.62 & 0.09 \\
\hline \multicolumn{7}{|c|}{ Statements contained in TABLE 8: Perceptions about $\varrho \varepsilon 2$} \\
\hline 8.1 & 1.49 & 1.50 & 0.85 & 1.57 & 1.40 & 0.34 \\
\hline 8.2 & 2.36 & 2.47 & 0.65 & 2.78 & 2.10 & 0.01 \\
\hline
\end{tabular}

Source: Created by author

On comparing the perceptions of students signed with 'Big Four' TIPP firms and other TIPP firms only one significant difference was noted. The students articled to 'Big Four' firms were more positive about the increased focus on leadership development $(p=.03)$. Regarding the statements contained in TABLE 6 (Perceptions regarding the value of the main changes), it can be seen that the mean score of students who had signed article contracts with 'Big Four' auditing firms were consistently lower than the mean score of students who had signed with 'Other' auditing firms. This indicates the students articled to 'Big Four' auditing firms were more positive about the changes and saw more value in them (possibly because they believed that the way the changes would be implemented by the 'Big Four' auditing firms would be more beneficial to trainees).

On comparing the responses of female and male students, two significant differences were noted. Females agreed to a larger extent that the change in training model was necessitated by 
the increasing use of information technology in the business world $(p=.02)$. Females were also more prone to be worried about the format of the Part II exam, when compared to their male counterparts $(p=.01)$. The female students also consistently had lower mean scores than their male counterparts regarding to statements contained in both TABLE 6 (Perceptions regarding the value of the main changes) and TABLE 7 (Perceptions of the effect of the changes). This indicates that the female students were more positive about the proposed changes (saw more value in it) and believed more strongly that it would cause both training offices and prospective trainees to act differently.

\section{CONCLUSION}

SAICA recently introduced a new training programme for prospective $C A(S A) s$, applicable to new trainees from 2010 onwards. The training programme was changed to enable the CA(SA) profession and its trainees to better address the needs of a changing business environment. The new training programme is competency-based and places increased emphasis on the nontechnical skills an accountant should possess, such as interpersonal and communication skills, leadership qualities, ethics, knowledge of corporate governance, as well as the effective usage of information technology.

The CTA class of a residential university was surveyed to ascertain their perceptions of the new training programme. The students still believed the CA(SA) profession to be highly regarded both in South Africa as well as internationally. Generally speaking, the students' perceptions regarding the new training programme ranged between neutral and positive. The students perceived the changes to be necessary, but were concerned about how it would be implemented in practice. Students felt somewhat positive about the fact that the new training programme allows trainees to choose a focus area (elective) and that they would gain more balanced experience (technical as well as professional skills). However, there was also a perception that the changes had been communicated too late, because the students had already signed training contracts with auditing firms, and were already committed to auditing as focus area.

The students believed that the availability of an elective will draw more students towards accountancy - an increase that could possibly help address the shortage of trainees and $\mathrm{CA}(\mathrm{SA})$ s. The students also felt that the existence of electives or focus areas would change the way students thought about employment at a certain training office, as the students would review whether the specific training office offered their preferred focus area, leading them to choose a training firm later in their studies. It was believed that the training offices would also have to change their marketing strategies (to include information about the electives offered) when attempting to attract students to sign a training contract. Training offices should take note of the above perceptions in designing their marketing campaigns.

The study also highlighted that it is important to students to know how they will be assessed, as can be seen from the uncertainty and worry regarding the format of $Q \varepsilon 2$. It is recommended that SAICA finalises and communicates this as soon as possible. 


\section{LIST OF REFERENCES}

American Institute of Certified Public Accountants (AICPA). (2005). Core Competency Framework \& Educationa/ Competency Assessment Web Site. [Online] Available:

http://www.aicpa.org/interestareas/accountingeducation/resources/pages/corecompetency.aspx (Accessed 18 July 2012).

Albrecht, W.S. \& Sack, R.J. (2000). Accounting education: charting the course through a perilous future. Accounting Education Series, 16. Sarasoto, Fla: American Accounting Association.

Barac, K. (2009). South African training officers' perceptions of the knowledge and skills requirements of entry-level trainee accountants. Meditari Accountancy Research, 17(2), pp. 19-46.

Bolt-Lee, C. \& Foster, S.D. (2002). The core competency framework: a new element in the continuing call for accounting education change in the United States. Accounting Education, 12(1), pp. 33-47.

Boritz, J.E. \& Carnaghan, C.A. (2003). Competency-based education and assessment of the accounting profession: a critical review. Canadian Accounting Perspectives, 2(1), pp. 7-34.

Canadian Institute of Chartered Accountants (CICA). (2011). The UFE Candidates' Competency Map. [Online] Available: http://www.cica.ca/becoming-a-ca/documents/item9604.pdf. (Accessed 18 July 2012).

Canadian Institute of Chartered Accountants (CICA). (2010). CA Practical Experience Requirements. [Online] Available: http://www.cica.ca/becoming-a-ca/documents/item9580.pdf. (Accessed 18 July 2012).

Dellaportas, S. (2006). Making a difference with a discrete course in accounting ethics. Journal of Business Ethics, 65, pp. 391-404.

Geiger, M.A. \& Ogilby, S.M. (2000). The first course in accounting: students' perceptions and their effect on the decision to major in accounting. Journal of Accounting Education, 18, pp. 63-78.

Ibrahim, N. \& Angelidis, J. (2009). The relative importance of ethics as a selection criterion for entrylevel public accountants: does gender make a difference? Journal of Business Ethics, 85, pp. 49-58.

Institute of Chartered Accountants in Australia (ICAA). (2010). Demonstrating competency. [Online] Available: http://www.charteredaccountants.com.au/Candidates/The-Chartered-AccountantsProgram/Practical-experience/Demonstrating-competency. (Accessed 18 July 2012).

Institute of Chartered Accountants in Ireland (ICAI). (2011). Chartered accountants Ireland

Competency Statement FAE. [Online] Available:

http://www.charteredaccountants.ie/Global/syllabus/FAE/FAE\%20Competency $\% 20$ Statement $\% 2020$ 11\%202012.pdf. (Accessed 18 July 2012).

International Federation of Accountants (IFAC). (2008). Framework for international education pronouncements. New York.

Jeacle, I. (2008). Beyond the boring grey: the construction of the colourful accountant. Critical Perspectives on Accounting, 19, pp. 1296-1320.

Palmer, K.N., Ziegenfuss, D.E. \& Pinsker, R.E. (2004). International knowledge, skills, and abilities of auditors/accountants: evidence from a recent competency study. Managerial Auditing Journal, 19(7), pp. 889-896. 
Saemann, G.P. \& Crooker, K.J. (1999). Student perceptions of the profession and its effect on decisions to major in accounting. Journal of Accounting Education, 17, pp. 1-22.

South African Institute of Chartered Accountants (SAICA). (2008). Competency framework. [Online] Available: http://www.saica.co.za/Portals/0/documents/CompetencyFramework_CAs_Summary.pdf. (Accessed 18 July 2012).

SAICA. (2009a). Slideshow: training officer 22 July 2009. [Online] Available:

https://www.saica.co.za/Portals/0/Trainees/documents/SlideShowTraining0fficer22July09.pdf.

(Accessed 18 July 2012).

SAICA. (2009b). Prospective trainees information document. [Online] Available:

https://www.saica.co.za/Portals/0/Trainees/documents/Prospective\%20trainees\%20information\%2

0document.pdf. (Accessed 18 July 2012).

SAICA. (2009c). $\rho E$ Part 1 Stats. [Online] Available:

https://www.saica.co.za/Portals/0/documents/QE_Part_I_2009_stats_for_Website.pdf. (Accessed 18 July 2012).

SAICA. (2009d). CA 2010 gap analysis research project. [Online] Available: https://www.saica.co.za/Portals/0/Trainees/documents/CA\%202010\%20Gap\%20Analysis.pdf. (Accessed 18 July 2012).

SAICA. (2009e). SAICA Trainee and Training Officer Satisfaction Survey. [Online] Available: https://www.saica.co.za/Portals/0/Trainees/documents/TraineeTraining0fficerSatisfaction2009.pd f. (Accessed 18 July 2012).

SAICA. (2012). Proposal for changes to the "Part I/" Exam as from 2014. [online] Available:

https://www.saica.co.za/learnersstudents/examinations/proposalforchangestopartiiexam/tabid/2 604/language/en-us/default.aspx. (Accessed 17 July 2012).

Wessels, P.L. \& Steenkamp, L.P. (2009). An investigation into students' perceptions of accountants. Meditari Accountancy Research, 17(1), pp. 117-132. 